\title{
A comparative review of maternal and neonatal outcome among pregnant women with COVID-19 in first and second wave in a tertiary care centre of South Rajasthan
}

\author{
Divya Chaudhary*, Madhubala Chauhan, Diksha Gupta, Shivraj Jat
}

Department of Obstetrics and Gynecology, RNT Medical College, Udaipur, Rajasthan, India

Received: 16 October 2021

Accepted: 11 November 2021

\section{*Correspondence:}

Dr. Divya Chaudhary,

E-mail: Dr.divyachaudhary@gmail.com

Copyright: ( $)$ the author(s), publisher and licensee Medip Academy. This is an open-access article distributed under the terms of the Creative Commons Attribution Non-Commercial License, which permits unrestricted non-commercial use, distribution, and reproduction in any medium, provided the original work is properly cited.

\section{ABSTRACT}

Background: Corona virus disease 2019 has taken a huge toll over health infrastructure and care all across the world. This article depicts our experience of COVID-19 in pregnant women and analyses maternal and neonatal outcome of same in first and second wave of this pandemic. Aim and objectives of the study were to compare the demographic characteristics, presenting features and fetomaternal outcome in COVID positive pregnant women in first v/s second wave in a tertiary care hospital.

Methods: The RTPCR COVID-19 positive pregnant women admitted during the period April-2020 to March-2021 were considered in $1^{\text {st }}$ wave of COVD-19 and that from April-2021 till June-2021 as $2^{\text {nd }}$ wave of COVID-19. Data like baseline characteristics, past medical, obstetric history, clinical presentation, laboratory results, imaging findings, management modalities, maternal and neonatal outcome were analysed and compared.

Results: Peak of $1^{\text {st }}$ wave of COVID-19 was found during the months of July-September 2020, while of $2^{\text {nd }}$ in AprilJune 2021. Most women presented with COVID-19 RTPCR positive were asymptomatic both in $1^{\text {st }}$ and $2^{\text {nd }}$ wave. Though most patients were managed on room air in both waves, $6.52 \%$ and $9.38 \%$ were on oxygen, $1.09 \%$ and $10.94 \%$ were managed with mechanical ventilation and BIPAP in $1^{\text {st }}$ and $2^{\text {nd }}$ wave respectively. There was significant $(p<0.05)$ increase in maternal deaths in the $2^{\text {nd }}$ wave $(7.03 \%)$ as compared to $1^{\text {st }}$ wave $(1.09 \%)$.

Conclusions: A significantly large number of patients were affected in $2^{\text {nd }}$ wave of COVID-19 pandemic with more morbidity and mortality. Neonatal population remained relatively unaffected in both waves.

Keywords: COVID-19, Maternal mortality, $2^{\text {nd }}$ Wave of COVID-19, Pregnancy in COVID

\section{INTRODUCTION}

Coronavirus disease 2019 (COVID-2019) caused by severe acute respiratory syndrome coronavirus-2 (SARSCoV-2), since its declaration as a pandemic by WHO on March,11, 20201, has taken a huge toll over health infrastructure and care all across the world. As of May 2021, over 170 million people all over the world have been infected, which represents approximately $2.15 \%$ of world population (170 million/ 7.9 billion). 3 million people lost their lives in this battle making the death rate of approximately $1.7 \%$. India has 28 million COVID-19 positive cases as of May 2021 with death of more than 3 lakh cases. $^{2}$

The effects of SARS-CoV-2 are influenced by patient's age and comorbidities. ${ }^{3}$ Pregnant women, due to their physiological changes of immunity and anatomical changes, were believed to be more susceptible to virus infection. ${ }^{4}$

This article depicts our experience of COVID-19 in pregnant women and analyses maternal and neonatal outcomes in $1^{\text {st }}$ and $2^{\text {nd }}$ wave of this pandemic. 


\section{Aim and objectives}

Aim and objectives of the study were to compare the demographic characteristics, presenting features and fetomaternal outcome in COVID positive pregnant women in First v/s Second wave in a tertiary care hospital of Southern Rajasthan.

\section{METHODS}

All pregnant women, coming to our centre, OPD or emergency, who met at least one of the criteria for COVID-19 testing were tested. The medical records of these pregnant women with laboratory confirmed COVID19 pneumonia and being admitted at RNT Medical College and Hospital, Udaipur between April 2020 to June 2021, were retrospectively reviewed. The patients admitted during the period April-2020 to March-2021 were considered in $1^{\text {st }}$ wave of COVD-19 and that from April2021 till June 2021 as of $2^{\text {nd }}$ wave of COVID-19. All pregnant women with RTPCR positive were advised admission. Those who refused admission at our centre or opted for the home isolation were not included in this study.

Criteria of COVID-19 testing at our institute included: Symptoms of COVID-19; History of exposure to people with COVID-19; travel history; coming from hot spot areas; undergoing operative caesarean delivery.

Such pregnant women were then subjected to RTPCR (SARS-CoV-2) on deep nasopharyngeal and pharyngeal samples. Sample collection, processing and laboratory testing were done according to WHO guidance. ${ }^{5}$ In this study, we have included 220 pregnant women who were admitted to our centre with RTPCR positive.

\section{Data collection}

Data collection was done using medical records of included patients presenting in RNTMC, Udaipur. Data included baseline characteristics, past medical history, obstetric history, clinical presentation, laboratory results, imaging findings, management modalities, maternal and neonatal outcome.

Classification of socioeconomic classes were done on the basis of Kuppuswamy's new classification.

\section{Statistical analysis}

Statistical analysis was done with SPSS, version 20.0. Continuous variables were directly expressed as a range. Categorical variables were expressed as number (\%). Parametric and non-parametric data were assessed according to tests applicable and results were analysed. $\mathrm{P}$ value of $<0.05$ was considered to be statistically significant.

\section{RESULTS}

Mean age of pregnant women with COVID-19 in $1^{\text {st }}$ wave was $27.37 \pm 5.05$ years with a range of 19 to 37 years and mean age in $2^{\text {nd }}$ wave was $26.89 \pm 5.25$ years. Average duration of stay at our centre was $8.21 \pm 3.6$ days in $1^{\text {st }}$ wave (range 3-17 days) and 17.46 \pm 2.40 days in $2^{\text {nd }}$ wave (range 8-23 days) which was significantly high. Mean BMI was $24.42 \pm 7.761^{\text {st }}$ wave and $25.52 \pm 4.372^{\text {nd }}$ wave. Gestational age at presentation was also similar in both waves.

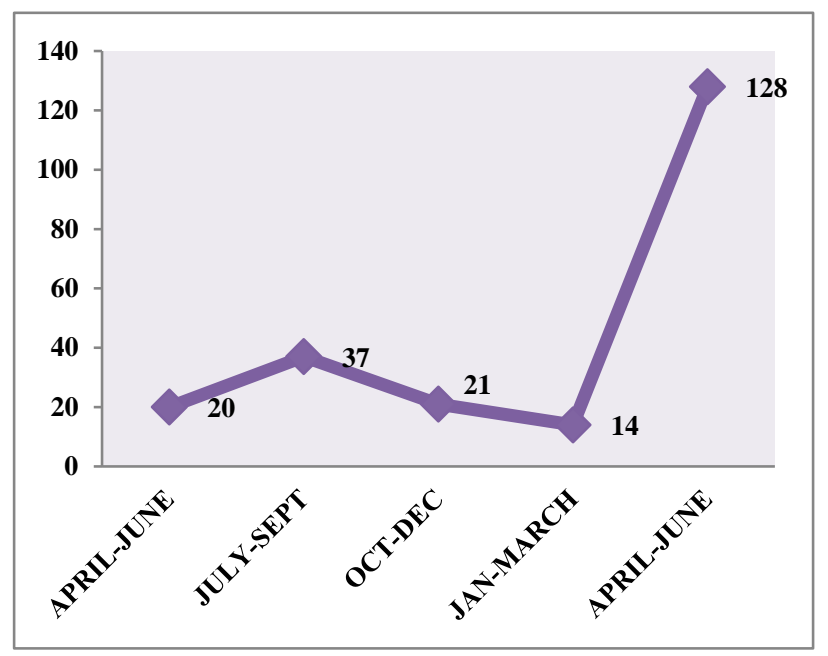

Figure 1: Number of COVID positive pregnant women admissions.

In $1^{\text {st }}$ wave of COVID-19 peak patients were found during the months of July-September 2020 which decreased in the months of Jan-March 2021, while a sudden rise was seen in the months of April-June 2021 with significantly higher number (128) of COVID-19 infected pregnant patients.

Most women presented with COVID-19 RTPCR positive were asymptomatic both in $1^{\text {st }}$ and $2^{\text {nd }}$ wave of COVID- 19 . In first wave fever was seen in $31.52 \%$, cough and myalgia in $25 \%$, loss of taste in $13.04 \%$, loss of smell in $8.70 \%$, headache in $5.43 \%$, sore throat in $3.26 \%$, diarrhoea in $2.17 \%$, shortness of breath in $2.17 \%$ and running nose/ cold in $1.09 \%$ each.

In second wave fever was seen in $46.87 \%$, cough in $34.37 \%$, myalgia in $42.19 \%$, headache in $20.31 \%$, loss of taste in $16.41 \%$, loss of smell in $17.19 \%$ and sore throat in $6.25 \%$, which were much more and statistically highly significant as compared to $1^{\text {st }}$ wave.

X-ray was also done in selected cases in $1^{\text {st }}$ and $2^{\text {nd }}$ wave of COVID-19. We found abnormal in $14(15.22 \%)$ and 27 $(21.09 \%)$ cases in $1^{\text {st }}$ and $2^{\text {nd }}$ wave respectively.

Most of the patients were managed on room air which included $90.22 \%$ in $1^{\text {st }}$ wave and $79.69 \%$ in $2^{\text {nd }}$ wave, $6.52 \%$ and $9.38 \%$ were on oxygen, $2.17 \%$ and $8.59 \%$ were on BIPAP $4.68 \%$ were managed with mechanical ventilation in $2^{\text {nd }}$ wave. 
There was significant $(\mathrm{p}<0.05)$ increase in maternal deaths in the $2^{\text {nd }}$ wave $(7.03 \%)$ as compared to $1^{\text {st }}$ wave $(1.09 \%)$.

In first wave of COVID-19, 17 (18.48\%) women had vaginal delivery, $50(54.35 \%)$ had caesarean section, 2 (2.17\%) had manual vacuum aspiration and $23(25 \%)$ were not delivered. In $2^{\text {nd }}$ wave $29(22.66 \%)$ had vaginal delivery, $63(49.22 \%)$ had caesarean section and 36 (28.13\%) didn't deliver. Fetal distress and previous CS were the major indications for LSCS.

In first wave of COVID-19 of all the 70 babies born to women with active COVID infection, $<1.5 \mathrm{~kg}$ was $4.29 \%$, $1.5-2 \mathrm{~kg}$ were $10 \%, 2-2.5 \mathrm{~kg}$ were $14.29 \%,>2.5 \mathrm{~kg}$ was $65.71 \%$, data not available for $5.71 \%$, since they came to us post-delivery. All the babies born to women with h/o COVID infection were $>2.5 \mathrm{~kg}$. APGAR score at $5 \mathrm{~min}$ was noted $\leq 5$ in 7 newborn (including 3 IUFD), 6 in 4, 7 in 10,8 in 15 , and 9 in 30 newborn babies. Data is not available for 4 outside delivered babies. Resuscitation was given to 11 babies at birth. Vertical transmission was seen in 2 babies out of all babies born with COVID-19 infection. No neonatal death was seen in babies of active COVID positive mothers.

In second wave of COVID-19 of all the 95 babies born to women with active infection and history of COVID infection, APGAR score at 5 min was noted $\leq 5$ in 7 newborn (including 5 IUFD), 6 in 3, 7 in 10, 8 in 37, and 9 in 35 newborn babies. Resuscitation was given to 10 babies at birth. Vertical transmission was seen in 3 babies. These findings were similar to that of the $1^{\text {st }}$ wave. Although five neonatal deaths were observed in babies of active COVID positive mothers. Reasons for neonatal death were meconium aspiration, RDS and extremely low birth weight. None of the neonates with COVID RTPCR positive died in the second wave of COVID-19.

Table 1: Demographic of data.

\begin{tabular}{|c|c|c|c|c|c|c|c|c|c|}
\hline \multirow{2}{*}{ Variables } & \multicolumn{4}{|c|}{$1^{\text {st }}$ wave, $(\mathrm{n}=92)$} & \multicolumn{4}{|c|}{$2^{\text {nd }}$ wave, $(n=128)$} & \multirow{2}{*}{$\mathbf{P}$ value } \\
\hline & Mean & SD & Min & Max & Mean & SD & Min & Max & \\
\hline Age (years) & 27.37 & 5.05 & 19 & 37 & 26.89 & 5.25 & 18 & 42 & 0.49 \\
\hline Duration of stay (days) & 8.21 & 3.6 & 3 & 17 & 17.46 & 2.40 & 10 & 23 & $0.001 *$ \\
\hline BMI & 24.42 & 7.76 & 19.3 & 32.1 & 25.52 & 4.37 & 21.1 & 32.2 & 0.08 \\
\hline GA at presentation & 34.87 & 7.36 & 8.2 & 40.4 & 36.38 & 5.31 & 16 & 41 & 0.09 \\
\hline
\end{tabular}

Table 2: Maternal parameters.

\begin{tabular}{|c|c|c|c|c|c|c|}
\hline \multirow{2}{*}{\multicolumn{2}{|c|}{ Variables }} & \multicolumn{2}{|c|}{$1^{\text {st }}$ wave, $(\mathrm{n}=92)$} & \multicolumn{2}{|c|}{$2^{\text {nd }}$ wave, $(\mathrm{n}=128)$} & \multirow{2}{*}{$P$ value } \\
\hline & & No. & $\%$ & No. & $\%$ & \\
\hline \multirow{2}{*}{ Area of living } & Rural & 46 & 50 & 71 & 55.47 & 0.423 \\
\hline & Urban & 46 & 50 & 57 & 44.53 & 0.423 \\
\hline \multirow{5}{*}{$\begin{array}{l}\text { Socio-economic } \\
\text { status }\end{array}$} & Lower & 12 & 13.04 & 12 & 9.38 & 0.389 \\
\hline & Lower middle & 32 & 34.78 & 37 & 28.91 & 0.354 \\
\hline & Middle & 40 & 43.48 & 66 & 51.56 & 0.237 \\
\hline & Upper middle & 5 & 5.43 & 9 & 7.03 & 0.632 \\
\hline & Upper & 3 & 3.26 & 4 & 3.13 & 0.955 \\
\hline \multirow{2}{*}{ Gravida } & Primi & 31 & 33.70 & 56 & 43.75 & \multirow{2}{*}{0.132} \\
\hline & Multi & 61 & 66.30 & 72 & 56.25 & \\
\hline \multirow{2}{*}{ Number of fetus } & Single & 77 & 83.69 & 125 & 97.66 & $0.001 *$ \\
\hline & Twins & 3 & 3.26 & 3 & 2.34 & 0.680 \\
\hline
\end{tabular}

Table 3: Maternal sign, symptoms, investigation and outcome.

\begin{tabular}{|c|c|c|c|c|c|c|}
\hline \multirow[b]{2}{*}{ Variables } & & \multicolumn{2}{|c|}{$1^{\text {st }}$ wave, $(\mathrm{n}=92)$} & \multicolumn{2}{|c|}{$2^{\text {nd }}$ wave, $(n=128)$} & \multirow[b]{2}{*}{ P value } \\
\hline & & No. & $\%$ & No. & $\%$ & \\
\hline \multirow{11}{*}{ Symptoms } & Asymptomatic & 57 & 61.96 & 91 & 71.09 & $0.011^{*}$ \\
\hline & Fever & 29 & 31.52 & 60 & 46.87 & $0.02 *$ \\
\hline & Cough & 23 & 25.00 & 44 & 34.37 & 0.136 \\
\hline & Loss of taste & 12 & 13.04 & 21 & 16.41 & 0.491 \\
\hline & Loss of smell & 8 & 8.70 & 22 & 17.19 & $0.05^{*}$ \\
\hline & Myalgia & 23 & 25.00 & 54 & 42.19 & $0.001 *$ \\
\hline & Headache & 5 & 5.43 & 26 & 20.31 & $0.001 *$ \\
\hline & Sore throat & 3 & 3.26 & 8 & 6.25 & 0.31 \\
\hline & Diarrhea & 2 & 2.17 & 4 & 3.13 & 0.67 \\
\hline & Shortness of breath & 2 & 2.17 & 26 & 20.31 & $0.001 *$ \\
\hline & Running nose & 1 & 1.09 & - & - & - \\
\hline
\end{tabular}




\begin{tabular}{|c|c|c|c|c|c|c|}
\hline \multirow{2}{*}{\multicolumn{2}{|c|}{ Variables }} & \multicolumn{2}{|c|}{$1^{\text {st }}$ wave, $(\mathrm{n}=92)$} & \multicolumn{2}{|c|}{$2^{\text {nd }}$ wave, $(n=128)$} & \multirow{2}{*}{ P value } \\
\hline & & No. & $\%$ & No. & $\%$ & \\
\hline \multirow{3}{*}{ TLC range } & $<11000$ & 51 & 55.43 & 85 & 66.41 & 0.098 \\
\hline & $11000-20000$ & 40 & 43.48 & 40 & 31.25 & 0.063 \\
\hline & $>20000$ & 1 & 1.09 & 3 & 2.34 & 0.491 \\
\hline \multirow{5}{*}{ CRP } & $<5$ & 2 & 2.17 & 6 & 4.69 & 0.326 \\
\hline & $5-25$ & 38 & 41.30 & 62 & 48.44 & 0.295 \\
\hline & $26-100$ & 41 & 44.57 & 46 & 35.94 & 0.197 \\
\hline & $>100$ & 0 & 0.00 & 14 & 10.94 & $0.001 *$ \\
\hline & Not done & 11 & 11.96 & 0 & 0.00 & $0.001 *$ \\
\hline \multirow{6}{*}{ IL-6 } & $0-7$ & 10 & 10.87 & 4 & 3.13 & $0.020 *$ \\
\hline & $8-14$ & 4 & 4.35 & 8 & 6.25 & 0.540 \\
\hline & $15-100$ & 20 & 21.74 & 25 & 19.53 & 0.689 \\
\hline & $101-500$ & 2 & 2.17 & 1 & 0.78 & 0.380 \\
\hline & $>500$ & 0 & 0.00 & 0 & 0.00 & - \\
\hline & Not done & 56 & 60.87 & 90 & 70.31 & 0.144 \\
\hline \multirow{4}{*}{ S. Ferritin } & Normal (50-150) & 16 & 17.39 & 12 & 9.38 & 0.078 \\
\hline & Raised & 6 & 6.52 & 25 & 19.53 & $0.006^{*}$ \\
\hline & Decreased & 14 & 15.22 & 0 & 0.00 & $0.001 *$ \\
\hline & Not done & 56 & 60.87 & 91 & 71.09 & 0.112 \\
\hline \multirow{4}{*}{$\begin{array}{l}\text { Platelet count } \\
\text { (Lakh) }\end{array}$} & $<0.5$ & 3 & 3.26 & 1 & 0.78 & 0.175 \\
\hline & $0.5-1$ & 5 & 5.43 & 7 & 5.47 & 0.991 \\
\hline & $1-1.5$ & 9 & 9.78 & 27 & 21.09 & $0.025^{*}$ \\
\hline & $>1.5$ & 75 & 81.52 & 93 & 72.66 & 0.127 \\
\hline \multirow{4}{*}{ X-ray } & $\begin{array}{l}\mathrm{B} / \mathrm{L} \text { ground glass } \\
\text { opacities }\end{array}$ & 13 & 14.13 & 25 & 19.53 & 0.296 \\
\hline & $\mathrm{B} / \mathrm{L}$ pleural effusion & 1 & 1.09 & 2 & 1.56 & 0.764 \\
\hline & $\begin{array}{l}\text { No abnormality } \\
\text { detected }\end{array}$ & 3 & 3.26 & 5 & 3.91 & 0.801 \\
\hline & Not done & 75 & 81.52 & 96 & 75.00 & 0.251 \\
\hline \multirow{4}{*}{ Managed with } & Room air & 83 & 90.22 & 102 & 79.69 & $0.035^{*}$ \\
\hline & Oxygen & 6 & 6.52 & 12 & 9.38 & 0.446 \\
\hline & BIPAP & 2 & 2.17 & 8 & 6.25 & 0.152 \\
\hline & $\begin{array}{l}\text { Mechanical } \\
\text { ventilation }\end{array}$ & 0 & 0 & 6 & 4.68 & $0.035^{*}$ \\
\hline Maternal & Deaths & 1 & 1.09 & 9 & 7.03 & $0.037 *$ \\
\hline
\end{tabular}

Table 4: Mode of delivery and indication of LSCS.

\begin{tabular}{|c|c|c|c|c|c|c|}
\hline \multirow{2}{*}{\multicolumn{2}{|c|}{ Variables }} & \multicolumn{2}{|c|}{$1^{\text {st }}$ wave, $(\mathrm{n}=92)$} & \multicolumn{2}{|c|}{$2^{\text {nd }}$ wave, $(\mathrm{n}=128)$} & \multirow{2}{*}{$P$ value } \\
\hline & & No. & $\%$ & No. & $\%$ & \\
\hline \multirow{4}{*}{ Mode of delivery } & Vaginal & 17 & 18.48 & 29 & 22.66 & 0.452 \\
\hline & LSCS & 50 & 54.35 & 63 & 49.22 & 0.453 \\
\hline & $\begin{array}{l}\text { Manual vacuum } \\
\text { aspiration }\end{array}$ & 2 & 2.17 & 0 & 0 & 0.094 \\
\hline & Not delivered & 23 & 25 & 36 & 28.13 & $0.001 *$ \\
\hline \multirow{9}{*}{$\begin{array}{l}\text { Indication of } \\
\text { LSCS }\end{array}$} & Malpresentation & 10 & 10.87 & 10 & 15.87 & 0.437 \\
\hline & Oligohydramnios & 19 & 20.65 & 13 & 10.16 & $0.001 *$ \\
\hline & CPD & 2 & 2.17 & 5 & 7.94 & 0.470 \\
\hline & $\begin{array}{l}\text { Cong. diaphragmatic } \\
\text { hernia in baby }\end{array}$ & 1 & 1.09 & - & - & - \\
\hline & Failed induction & 2 & 2.17 & 8 & 12.70 & 0.152 \\
\hline & Fetal distress & 10 & 10.87 & 17 & 26.98 & 0.591 \\
\hline & $\begin{array}{l}\text { Maternal } \\
\text { request }\end{array}$ & 1 & 1.09 & 4 & 6.35 & 0.317 \\
\hline & PIH (Severe) & 3 & 3.26 & - & - & - \\
\hline & Previous CS & 12 & 13.04 & 16 & 25.40 & 0.905 \\
\hline
\end{tabular}


Table 5: Neonatal outcome.

\begin{tabular}{|c|c|c|c|c|c|c|}
\hline \multirow{2}{*}{\multicolumn{2}{|c|}{ Variables }} & \multicolumn{2}{|c|}{$1^{\text {st }}$ wave, $(n=70)$} & \multicolumn{2}{|c|}{$2^{\text {nd }}$ wave, $(\mathrm{n}=95)$} & \multirow{2}{*}{$P$ value } \\
\hline & & No. & $\%$ & No. & $\%$ & \\
\hline \multirow{5}{*}{ Birth weight (kg) } & $<1.5$ & 3 & 4.29 & 4 & 4.21 & \multirow{5}{*}{0.77} \\
\hline & $1.5-2$ & 7 & 10 & 14 & 14.74 & \\
\hline & $2-2.5$ & 10 & 14.29 & 10 & 10.53 & \\
\hline & $>2.5$ & 46 & 65.71 & 64 & 67.37 & \\
\hline & Data not available & 4 & 5.71 & 3 & 3.16 & \\
\hline \multirow{6}{*}{ APGAR at 5 min } & $\leq 5$ & 7 & 10 & 7 & 7.37 & \multirow{6}{*}{0.27} \\
\hline & 6 & 4 & 5.71 & 3 & 3.16 & \\
\hline & 7 & 10 & 14.29 & 10 & 10.53 & \\
\hline & 8 & 15 & 21.43 & 37 & 38.95 & \\
\hline & 9 & 30 & 42.86 & 35 & 36.84 & \\
\hline & Data not available & 4 & 5.71 & 3 & 3.16 & \\
\hline \multirow{3}{*}{$\begin{array}{l}\text { Resuscitation at } \\
\text { delivery }\end{array}$} & Yes & 11 & 15.71 & 10 & 10.53 & \multirow{3}{*}{0.41} \\
\hline & No & 55 & 78.57 & 82 & 86.32 & \\
\hline & Data not available & 4 & 5.71 & 3 & 3.16 & \\
\hline \multirow{3}{*}{$\begin{array}{l}\text { Vertical } \\
\text { transmission }\end{array}$} & Yes & 2 & 2.86 & 3 & 3.16 & \multirow{3}{*}{0.72} \\
\hline & No & 64 & 91.43 & 89 & 93.68 & \\
\hline & Not available & 4 & 5.71 & 3 & 3.16 & \\
\hline \multirow{2}{*}{ Neonatal death } & Yes & 0 & 0.00 & 5 & 5.26 & \multirow{2}{*}{$0.05^{*}$} \\
\hline & No & 70 & 100 & 90 & 94.74 & \\
\hline \multirow{2}{*}{ IUFD } & Yes & 3 & 4.28 & 5 & 5.26 & \multirow{2}{*}{0.25} \\
\hline & No & 67 & 95.72 & 90 & 94.74 & \\
\hline \multirow{10}{*}{$\begin{array}{l}\text { Newborn } \\
\text { complications }\end{array}$} & COVID positive & 2 & 2.86 & 3 & 3.16 & 0.91 \\
\hline & Lbw & 20 & 28.57 & 28 & 29.47 & 0.90 \\
\hline & NICU admission & 9 & 12.86 & 14 & 14.74 & 0.73 \\
\hline & Preterm & 15 & 21.43 & 25 & 26.32 & 0.47 \\
\hline & Msl & 7 & 7.60 & 10 & 10.53 & 0.91 \\
\hline & Neonatal hypoglycemia & 1 & 1.43 & 0 & 0.00 & 0.24 \\
\hline & RDS & 4 & 5.71 & 11 & 11.58 & 0.19 \\
\hline & $\begin{array}{l}\text { Cong. diaphragmatic } \\
\text { hernia in baby }\end{array}$ & 1 & 1.43 & 0 & 0.00 & 0.24 \\
\hline & None & 44 & 62.86 & 65 & 68.42 & 0.46 \\
\hline & Data not available & 4 & 5.71 & 3 & 3.16 & 0.42 \\
\hline
\end{tabular}

\section{DISCUSSION}

With each passing day with COVID-19 and rapidly mutating strains, we are coming across a wide range of manifestations in different individuals. As a result of which the guidelines for managing these patients are changing rapidly as well. Although the death rate, in general population, due to COVID-19 infection is low, the evidence of the same for pregnant women is grossly lacking. We suggest more and more data to be published, so as to get the trend of COVID-19 infection in pregnant women and maternal and neonatal outcome can be compared.

The report from center for disease control and prevention (CDC) compared 8,207 cases of COVID-19 in pregnant women with 83,205 cases in non-pregnant women. ${ }^{6}$ Although the report showed a higher number of hospitalizations, ICU admissions, mechanical ventilation among the pregnant group but death rate among these two groups was found to be similar. In our study, during the $2^{\text {nd }}$ wave, the need for mechanical ventilation was significantly higher during pregnancy $6(4.68 \%)$ as compared to none in $1^{\text {st }}$ wave. Also, the maternal death rate during $2^{\text {nd }}$ wave $(7.03 \%)$ pregnancy was significantly high as compared to $1^{\text {st }}$ wave (1.09\%). Also, the neonatal deaths were significantly more $5(5.26 \%)$ during the $2^{\text {nd }}$ wave delivery as compared to none in the $1^{\text {st }}$ wave but none was due to COVID infection per se.

Fever was present in $29(31.52 \%)$ cases in the $1^{\text {st }}$ wave as compared to $60(46.87 \%)$ cases in $2^{\text {nd }}$ wave, similarly symptoms like cough, myalgia, headache and shortness of breath were also much more during the $2^{\text {nd }}$ wave of COVID-19. Our findings were similar to findings reported by Juan et al in their study during the $1^{\text {st }}$ wave..$^{13}$

Although most common pregnant ladies diagnosed with COVID were asymptomatic i.e., $61.92 \%$ in 1 st wave and $71.09 \%$ in second wave, most common symptoms were fever, cough and myalgia. Headache and diarrhoea were seen less common. Most of the asymptomatic women had laboratory findings also in normal limits. In $1^{\text {st }}$ wave leukocytosis was seen in 41 women (44.56\%). Raised CRP 
$(>5)$ in 79 women, raised IL-6 (>7) in 26 women and raised ferritin (>150) seen in 6 women and that in second wave, leukocytosis was there in 43, raised CRP in 122 women, raised IL- 6 in 34 and raised ferritin in 25 women. Of all women with raised ferritin, all had severe symptoms of COVID-19 infection. More studies are required to establish S. ferritin as a good marker of severity of COVID. X-ray was done only in selected cases with moderate to severe symptoms or atypical symptoms and were found abnormal in 14 cases out of $17 \mathrm{X}$-rays in $1 \mathrm{st}$ wave and in 27 out of $32 \mathrm{X}$-rays done in $2^{\text {nd }}$ wave. CT scan was not done in any of our cases. D-dimer was also not done at our centre. Most of the cases were managed on room air during $1^{\text {st }}$ wave $(90.22 \%)$ as well as during $2^{\text {nd }}$ wave $(79.69 \%)$ but the need of mechanical ventilation was significantly high in $2^{\text {nd }}$ wave, no one in $1^{\text {st }}$ wave compared to 6 cases in second wave $(4.68 \%)$. The case-fatality rate of $1^{\text {st }}$ wave $(0.43 \%)$ is lower than the mortality of COVID19 patients reported by world health organization $(6.80 \%)$ and the Chinese center for disease control and prevention $(2.29 \%)$ and similar to the overall maternal mortality rate worldwide during the $1^{\text {st }}$ wave ( 1 in 180) while in $2^{\text {nd }}$ wave the scenario got totally changed and a significant 9 maternal deaths $(7.03 \%)$ were seen. ${ }^{8-10}$

The average gestational age among women who were delivered was 34.87 in $1^{\text {st }}$ wave and 36.38 weeks in $2^{\text {nd }}$ wave. This is different from Chinese study where average gestational age was 38.1 weeks. ${ }^{10}$ The rate of preterm birth in $1^{\text {st }}$ wave was $21.43 \%$ and $26.32 \%$ in second wave. This is different from 55/57 preterm births in China, and 32/57 from Italy. ${ }^{11} 54.35 \%$ in $1^{\text {st }}$ wave and $49.22 \%$ of women in $2^{\text {nd }}$ wave underwent caesarean delivery, Juan et al, from Italy, and a study in the United States showed a bit different result. ${ }^{12,13}$

No neonatal deaths secondary to COVID-19 were reported in this study. In a Chinese report the NICU admission rate was 134 of 137 newborns, similar reports were from the United States. ${ }^{12}$ In this study the overall NICU admission rate was $12.86 \%$ in $1^{\text {st }}$ wave and $14.74 \%$ in $2^{\text {nd }}$ wave. There were $2(2.86 \%)$ in $1^{\text {st }}$ wave and $3(3.16 \%)$ cases of vertical transmission among 95 deliveries in $2^{\text {nd }}$ wave. Findings of Juan et al are different who reported none in 310 deliveries to have vertical transmission, for which reversetranscription polymerase chain reaction data were made available. $^{13}$

We acknowledge that the true effect of the virus on both maternal and fetal morbidity and mortality will only be evident overtime.

\section{CONCLUSION}

Though the duration of $1^{\text {st }}$ wave was longer than $2^{\text {nd }}$ wave, a significantly large number of patients were affected in $2^{\text {nd }}$ wave of COVID-19 pandemic with more morbidity and mortality. Vertical transmission was seen in few neonates. Neonatal population remained relatively unaffected in both $1^{\text {st }}$ as well as $2^{\text {nd }}$ wave. Many more patients required mechanical ventilation, but most of the women were managed on room air. As there was rise in the maternal mortality and morbidity during the $2^{\text {nd }}$ wave, which was alarming, hence vaccination drive for pregnant women needs to be boosted.

\section{Funding: No funding sources}

Conflict of interest: None declared

Ethical approval: The study was approved by the Institutional Ethics Committee

\section{REFERENCES}

1. WHO. Rolling updates on coronavirus disease (COVID19). 2020. Available at: https:/www.who.int/emergencies/diseases/novelcoronavirus-2019/events-asthey-happen. Accessed on https://coronavirus.jhu.edu/map.html. Accessed on March 25, 2020.

2. Zhou F, Yu T, Du R, Fan G, Liu Y, Liu Z et al. Clinical course and risk factors for mortality of adult inpatients with COVID-19 in Wuhan, China: a retrospective cohort study. Lancet. 2020;395:103854.

3. Tan EK, Tan EL. Alterations in physiology and anatomy during pregnancy. Best Pract Res Clin Obstet Gynaecol. 2013;27(6):791-802.

4. WHO Laboratory testing for 2019 novel coronavirus (2019-nCoV) in suspected human cases. Interim guidance. Available at: https://www.who.int/publications-detail/laboratorytesting-for-2019-novel-coronavirus-in-suspectedhuman-cases-20200117. Accessed on Jan 17, 2020.

5. Ellington S, Strid P, Tong VT, Woodworth K, Galang RR, Zambrano LD et al. Characteristics of women of reproductive age with laboratory-confirmed SARSCoV-2 infection by pregnancy status-United States, January 22-June 7, 2020. MMWR Morb Mortal Wkly Rep. 2020;69:769-75.

6. Naccasha N, Gervasi MT, Chaiworapongsa T, Berman S, Yoon BH, Maymon E et al. Phenotypic and metabolic characteristics of monocytes and granulocytes in normal pregnancy and maternal infection. Am J Obstet Gynecol. 2001;185(5):111823.

7. Kalafat E, Yaprak E, Cinar G, Varli B, Ozisik S, Uzun C. Lung ultrasound and computed tomographic findings in pregnant woman with COVID-19. Ultrasound Obstet Gynecol. 2020;55(6):835-7.

8. Karami P, Naghavi M, Feyzi A, Aghamohammadi M, Novin MS, Mobaien A. Mortality of a pregnant patient diagnosed with COVID-19: A case report with clinical, radiological, and histopathological findings. Travel Med Infect Dis. 2020;101665.

9. Wang D, Hu B, Hu C, Zhu F, Liu X, Zhang J. Clinical Characteristics of 138 Hospitalized Patients With 2019 Novel Coronavirus-Infected Pneumonia in Wuhan, China. JAMA. 2020;323(11):1061-9.

10. Buonsenso D, Raffaelli F, Tamburrini E, Biasucci DG, Salvi S, Smargiassi A. Clinical role of lung 
ultrasound for the diagnosis and monitoring of COVID-19 pneumonia in pregnant women. Ultrasound Obstet Gynecol. 2020;22055.

11. Iqbal SN, Overcash R, Mokhtari N, Saeed H, Gold S, Auguste T. An Uncomplicated Delivery in a Patient with COVID-19 in the United States. N Engl J Med. 2020;382(16):e34.
12. Juan J, Gil M, Rong Z, Zhang Y, Yang H, Poon LC. Effects of coronavirus disease 2019 (COVID-19) on maternal, perinatal and neonatal outcomes: a systematic review. China Ultrasound in Obstet Gynae. 2020;56(1):15-27.

Cite this article as: Chaudhary D, Chauhan M, Gupta D, Jat S. A comparative review of maternal and neonatal outcome among pregnant women with COVID-19 in first and second wave in a tertiary care centre of South Rajasthan. Int J Reprod Contracept Obstet Gynecol 2021;10:4471-7. 